\title{
Formation of Mercury Adatom Layer by Simple Dipping Method for the Oxygen Reduction and Its Application to an Al-air Fuel Cell ${ }^{\dagger}$
}

\author{
Guang Shan Xuan, Yan-Ling Gong, Hyung Joo Kim, ${ }^{\ddagger}$ and Sunghyun Kim ${ }^{\S, *}$ \\ Department of Pharmacy, Qingdao University of Science \& Technology, Qingdao, 266042, China \\ ${ }^{\ddagger}$ Department of Microbial Engineering, Konkuk University, Seoul 143-701, Korea \\ ${ }^{\S}$ Department of Bioscience and Biotechnology, Konkuk University, Seoul 143-701, Korea. *E-mail: skim100@konkuk.ac.kr \\ Received July 3, 2010, Accepted August 7, 2010
}

Key Words: $\mathrm{Hg}$ adatom layer, $\mathrm{O}_{2} / \mathrm{H}_{2} \mathrm{O}_{2}$ reduction, Al-air fuel cell

The electrocatalytic reduction of oxygen is of prime importance in view of its practical applications for developing cathodes in fuel cells and metal-air batteries. ${ }^{1-4}$ Since the cathode performance is directly affected by the oxygen reduction overpotential, a lot of effort has been poured on the development of better electrocatalysts having less potential loss. Reaction mechanisms and rates vary with electrode materials, 5,6 crystallographic orientations, ${ }^{7,8}$ and reaction environments. ${ }^{9}$ In aqueous solution, oxygen reduction usually proceeds via consecutive two-electron processes, being reduced to hydrogen peroxide and then to water. There is no doubt that the best way is to reduce oxygen directly to water. This four-electron process, however, is not easy to achieve. Despite the fact that many ingenious methods and new materials have been devised, the search for the four-electron reduction electrocatalysts is still under way. They include various materials such as carbon-supported platinum, ${ }^{10}$ metal macrocycles, ${ }^{11,12}$ and 1,4,5,8-naphthalenetetronemodified gold. ${ }^{13}$ Biological systems such as laccase ${ }^{14}$ and cytochrome c oxidase ${ }^{15}$ have also been investigated.

Recently Matsumoto and coworkers ${ }^{16,17}$ reported that mercury adatom-modified gold electrodes prepared by underpotential deposition (upd) showed catalytic activities toward both oxygen and hydrogen peroxide reduction. Oxygen reduction, notably enough, proceed by four-electron reduction to water on the $\mathrm{Au} / \mathrm{Hg}$ electrodes, while two-electron process has been observed both on $\mathrm{Au}$ and $\mathrm{Hg}$ electrodes. ${ }^{18}$

In this work, we report a simple and reproducible way to prepare mercury-deposited gold electrodes by simply dipping $\mathrm{Au}$ in a mercury ion-containing solution. Thus prepared electrodes were used as a cathode in an alkaline-air fuel cell.

Fig. 1 shows XPS spectra for $\mathrm{Hg}$-adlayers formed on the $\mathrm{Au}$ surface by dipping and UPD. Two peaks at $84.6 \mathrm{eV}$ (or $84.5 \mathrm{eV}$ ) and $88.3 \mathrm{eV}$ (or $88.2 \mathrm{eV}$ ) correspond to $\mathrm{Au} 4 \mathrm{f}_{7 / 2}$ and $\mathrm{Au} 4 \mathrm{f}_{5 / 2}$, respectively, and two peaks at $100.5 \mathrm{eV}$ (or $100.4 \mathrm{eV}$ ) and $104.5 \mathrm{eV}$ (or $104.4 \mathrm{eV}$ ) to $\mathrm{Hg} 4 \mathrm{f}_{7 / 2}$ and $\mathrm{Hg} 4 \mathrm{f}_{5 / 2}$, respectively. ${ }^{19}$ The essentially same $\mathrm{Hg}$ peak positions within experimental error indicate that the oxidation state of $\mathrm{Hg}$ in both electrodes is identical. Metallic mercury gives a binding energy of $4 \mathrm{f}_{7 / 2}$ at $99.9 \mathrm{eV}^{19}$ Upon oxidation to $\mathrm{Hg}^{2+}$ it increases to $100.5 \mathrm{eV}$ with $104.6 \mathrm{eV}$ for $4 \mathrm{f}_{5 / 2}$. $^{19,20}$ Our XPS results indicate that mercury in both electrodes exists in a divalent state. $\mathrm{Hg}^{2+}$ ions are adsorbed on the Au surface by dipping. The possible reason why

${ }^{\dagger}$ This paper is dedicated to Professor Hasuck Kim for his outstanding contribution to electrochemistry and analytical chemistry.
$\mathrm{Hg}$ is still in +2 state for $\mathrm{Au}-\mathrm{Hg}($ upd) is that $\mathrm{Hg}$ is oxidized by oxygen in air during sample transfer.

Panel A of Fig. 2 is the linear sweep voltammetry (LSV) of oxygen reduction at a $\mathrm{Au}-\mathrm{Hg}($ dip) (solid) and a $\mathrm{Au}-\mathrm{Hg}$ (upd) (dotted) electrode. Molecular oxygen is irreversibly reduced at both electrodes. Almost identical voltammograms indicate that $\mathrm{Hg}$ adatom layers prepared by dipping and UPD have the same effect on the oxygen reduction. Charges under the peak were plotted against the dipping time (Panel B). Charges quickly increased with time and reached a limiting value within $100 \mathrm{~s}$. This implies that further $\mathrm{Hg}$ atoms are not adsorbed on the $\mathrm{Au}$ surface once a full $\mathrm{Hg}$ adlayer is formed. In this experiment, we fixed the dipping time at $120 \mathrm{~s}$.

The electrocatalytic nature of the $\mathrm{Au}-\mathrm{Hg}$ (dip) toward oxygen reduction is demonstrated in Fig. 3, in which LSVs at a bare $\mathrm{Au}$ (curves a and c) and a $\mathrm{Au}-\mathrm{Hg}(\mathrm{dip})(\mathrm{b}, \mathrm{d})$ for $\mathrm{N}_{2}-(\mathrm{a}, \mathrm{b})$ and $\mathrm{O}_{2}$-saturated (c, d) solutions. Two consecutive reduction waves were observed at a polycrystalline bare $\mathrm{Au} .{ }^{16}$ Oxygen is reduced to $\mathrm{HO}_{2}{ }^{-}$and then to $\mathrm{OH}^{-}$although the direct reduction to $\mathrm{OH}^{-}$ has been reported. ${ }^{22}$ The different results are due to the different crystallographic faces exposed on the Au surface. ${ }^{23}$ At a Au$\mathrm{Hg}$ (dip) electrode, however, only a single reduction wave was observed and the peak potential was shifted to $-0.18 \mathrm{~V}$ from $-0.43 \mathrm{~V}$ for a bare $\mathrm{Au}$, indicating the catalytic nature of this electrode toward the oxygen reduction.

The irreversible reduction of molecular oxygen is thought to

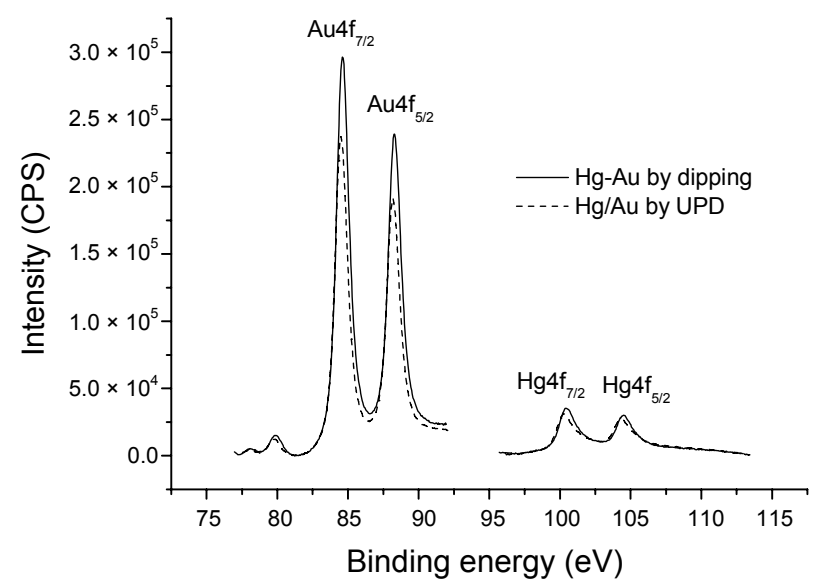

Figure 1. Au4f and $\mathrm{Hg} 4 \mathrm{f}$ peaks by $\mathrm{X}$-ray photoelectron spectroscopy for $\mathrm{Hg}$ adatom layers prepared by dipping (solid) and underpotential deposition (dashed) methods. 
(A)
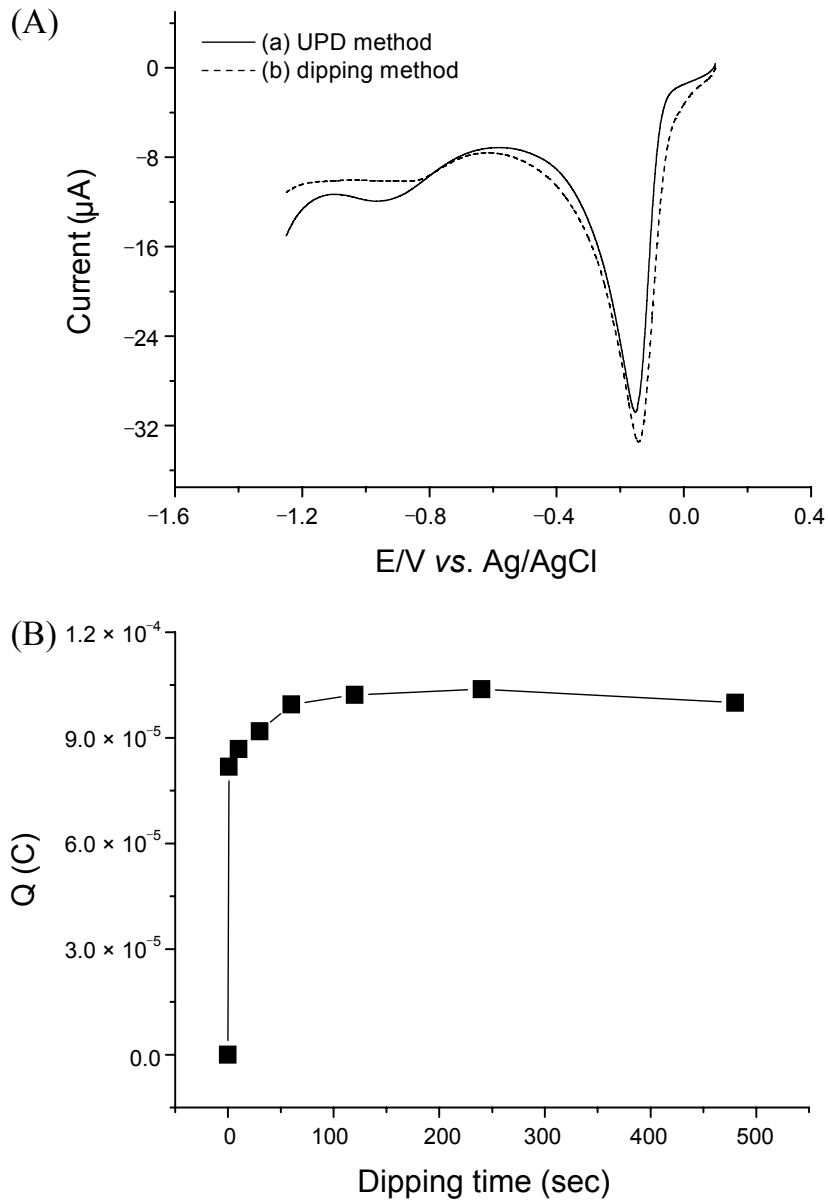

Figure 2. (A) Linear sweep voltammetry at $\mathrm{Au}-\mathrm{Hg}(\mathrm{upd})$ (solid) and $\mathrm{Au}-\mathrm{Hg}$ (dip) (dashed) electrodes in air-saturated $0.1 \mathrm{M} \mathrm{KOH}$ solution. Scan rate $=50 \mathrm{mV} \cdot \mathrm{sec}^{-1}$. (B) Plot of charge $v s$. dipping time for the oxygen reduction peak shown in $(\mathrm{A})$.

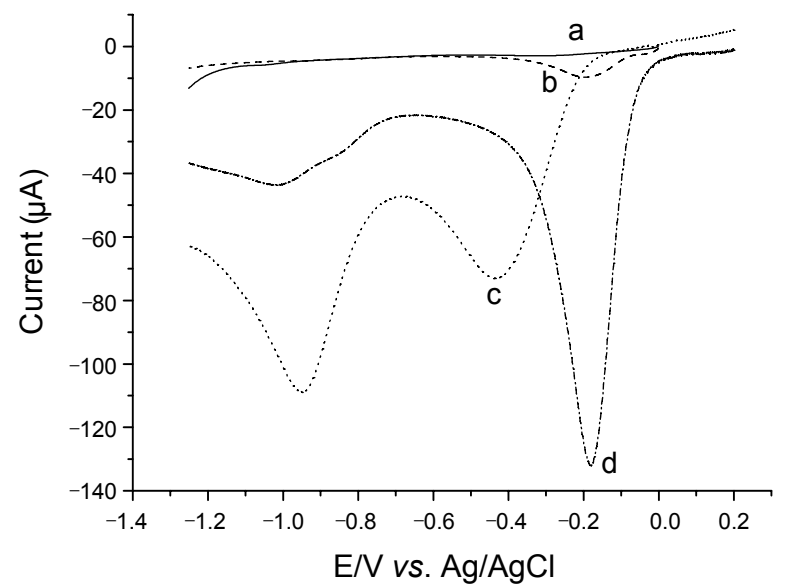

Figure 3. Linear sweep voltammetry at a bare $\mathrm{Au}$ (a and c) and a $\mathrm{Au}-\mathrm{Hg}(\mathrm{dip})\left(\mathrm{b}\right.$ and d) electrodes for $\mathrm{N}_{2}$-saturated ( $\mathrm{a}$ and $\mathrm{b}$ ) and $\mathrm{O}_{2}-$ saturated (c and d) $0.1 \mathrm{M} \mathrm{KOH}$ solutions. Scan rate $=50 \mathrm{mV} \cdot \mathrm{sec}^{-1}$. Inset: cyclic voltammograms for oxygen reduction at a $\mathrm{Au}-\mathrm{Hg}(\mathrm{dip})$ electrode for various oxygen percentages.

proceed to produce hydroxide ion via the formation of hydrogen peroxide. Fig. 4 is cyclic voltammograms of $\mathrm{H}_{2} \mathrm{O}_{2}$ of various concentrations in $0.1 \mathrm{M} \mathrm{KOH}$ solution. Although the reduction

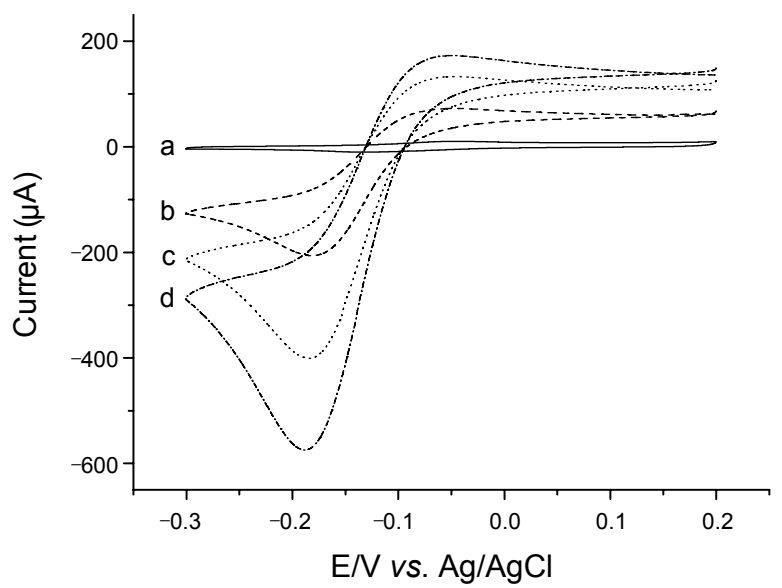

Figure 4. Cyclic voltammetry at a $\mathrm{Au}-\mathrm{Hg}$ (dip) electrode for different $\mathrm{H}_{2} \mathrm{O}_{2}$ concentrations of (a) zero, (b) $4.3 \times 10^{-5} \mathrm{M}$, (c) $8.7 \times 10^{-3} \mathrm{M}$, and (d) $1.3 \times 10^{-2} \mathrm{M}$. Scan rate $=50 \mathrm{mV} \cdot \mathrm{sec}^{-1}$.

current does not seem to linearly increase with the increase in $\mathrm{H}_{2} \mathrm{O}_{2}$ concentration, the reduction potential is very close to that of oxygen reduction. Molecular oxygen is reduced to hydrogen peroxide $\left(\mathrm{HO}_{2}{ }^{-}\right)$by the two-electron process (Eq. 1 below) and produced $\mathrm{HO}_{2}{ }^{-}$is further reduced to peroxide ion (Eq. 2) by the two-electron process. The overall reaction is the four-electron reduction of oxygen to $\mathrm{OH}^{-}$. This was confirmed by Matsumoto et al. ${ }^{16}$ who showed in their rotating ring disk electrode experiments that no oxidation current at the ring electrode was observed for the oxygen reduction occurred at the disk electrode, indicating that $\mathrm{OH}^{-}$was formed by the four-electron reduction process. The following reduction mechanism at a $\mathrm{Au}-\mathrm{Hg}$ (dip) could be written.

$$
\begin{aligned}
& \mathrm{O}_{2}+\mathrm{H}_{2} \mathrm{O}+2 \mathrm{e}^{-} \rightarrow \mathrm{HO}_{2}^{-}+\mathrm{OH}^{-} \\
& \mathrm{HO}_{2}^{-}+\mathrm{H}_{2} \mathrm{O}+2 \mathrm{e}^{-} \rightarrow 3 \mathrm{OH}^{-} \\
& \text {Overall: } \mathrm{O}_{2}+2 \mathrm{H}_{2} \mathrm{O}+4 \mathrm{e}^{-} \rightarrow 4 \mathrm{OH}^{-}
\end{aligned}
$$

Another possibility is the decomposition of $\mathrm{H}_{2} \mathrm{O}_{2}$ in highly alkaline solutions into oxygen and water. Even in this case, produced oxygen undergoes a series of reduction reactions to $\mathrm{OH}^{-}$as shown above.

Adsorbed hydroxides $\left(\mathrm{OH}_{\text {ads }}{ }^{-}\right)$may play an important role in the reduction of oxygen. Adzic and coworkers ${ }^{24}$ reported in their Au single crystal works that the origin of the catalytic activity was attributed to the formation of partly discharged $\mathrm{OH}^{-}$species $\left(\mathrm{OH}_{\mathrm{ads}}{ }^{(1-\delta)^{-}}\right)$on the surface. The same explanation was given to the $\mathrm{Hg}$ adatom-modified Au surface by UPD. In our case of $\mathrm{Au}-\mathrm{Hg}$ (dip) electrodes, we also observed the formation of adsorbed $\mathrm{OH}^{-}$species (data not shown). The higher amount of adsorbed $\mathrm{OH}^{-}$species on the $\mathrm{Au}-\mathrm{Hg}$ (dip) surface than on the bare Au surface explains a better catalytic activity of the former compared to the unmodified Au surface.

$\mathrm{Au}-\mathrm{Hg}$ (dip) electrodes have been applied to the aluminumair semi-fuel cell as a cathode. While there has been much effort to develop aluminum-hydrogen peroxide fuel cells as green power sources, ${ }^{25,26}$ a relatively small number of researches have 
(A)

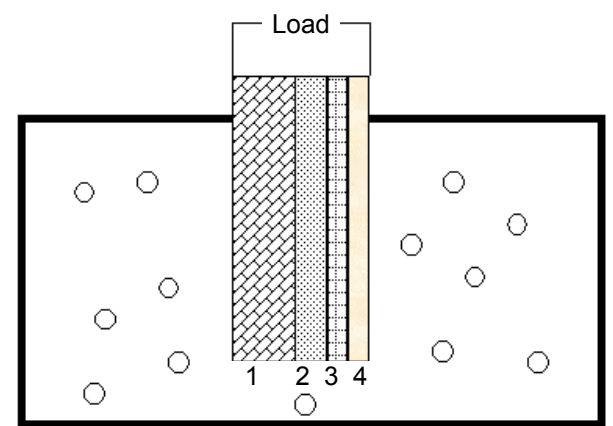

O: Oxygen, 1: Aluminium, 2: Nylon, 3: PE, 4: Hg-Au electrode

(B)

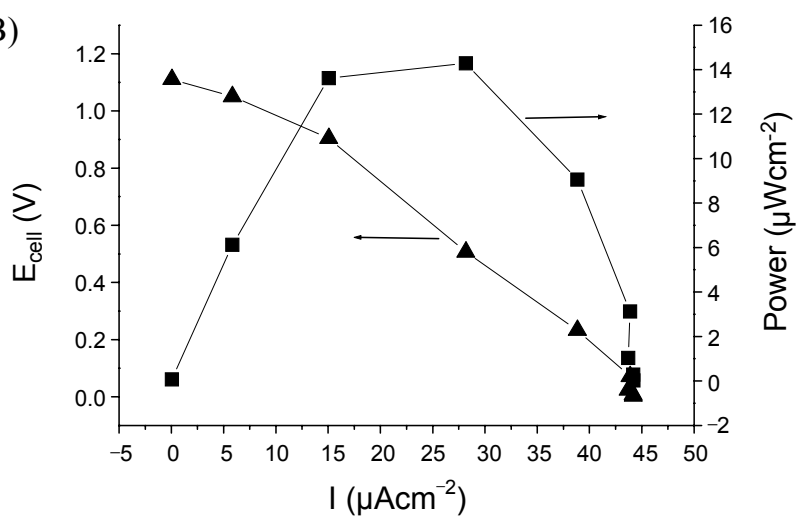

Figure 5. (A) Schematic diagram of an aluminum-air semi-fuel cell constructed using a $\mathrm{Au}-\mathrm{Hg}(\mathrm{dip})$ cathode. (B) Polarization ( $\mathbf{\Lambda})$ and power density $(\mathbf{\square})$ curves in an air-saturated $0.1 \mathrm{M} \mathrm{KOH}$ solution.

been conducted on the aluminum-oxygen fuel cells. We constructed an $\mathrm{Al}-\mathrm{O}_{2}$ cell that consisted of an $\mathrm{Al}$ foil anode $(0.8$ $\left.\mathrm{cm}^{2}\right)$, a $\mathrm{Au}-\mathrm{Hg}(\mathrm{dip})$ cathode $\left(0.6 \mathrm{~cm}^{2}\right)$ prepared from a Ausputtered PVC, and an air-saturated $0.1 \mathrm{M} \mathrm{KOH}$ solution (Fig. $5 \mathrm{~A})$. A nylon membrane was set between the anode and the cathode. The following reactions take place:

$$
\begin{aligned}
& \text { At anode: } 4 \mathrm{Al}(s)+16 \mathrm{OH}^{-}(a q) \rightarrow \\
& \qquad 4 \mathrm{AlO}_{2}^{-}(a q)+8 \mathrm{H}_{2} \mathrm{O}(l)+12 \mathrm{e}^{-} \\
& \text {At cathode: } 3 \mathrm{O}_{2}+6 \mathrm{H}_{2} \mathrm{O}(l)+12 \mathrm{e}^{-} \rightarrow 12 \mathrm{OH}^{-}(a q) \\
& \text { Overall: } 4 \mathrm{Al}^{(s)}+3 \mathrm{O}_{2}+4 \mathrm{OH}^{-}(a q) \rightarrow \\
& 4 \mathrm{AlO}_{2}^{-}(a q)+2 \mathrm{H}_{2} \mathrm{O}(l)
\end{aligned}
$$

A polarization curve was constructed by changing external loads (Fig. 5B). The initial open circuit voltage of about $1.5 \mathrm{~V}$ gradually decreased to 1.1 to $1.2 \mathrm{~V}$ due to the aluminum hydroxide layer formation on the aluminum surface. ${ }^{25}$ The maximum power density of $14.3 \mu \mathrm{W} \cdot \mathrm{cm}^{-2}$ is quite lower than those of chemical fuel cells. This result, however, shows the possibility of using oxygen as a cathodic fuel and $\mathrm{Au}-\mathrm{Hg}(\mathrm{dip})$ as an electrocatalyst for oxygen reduction.

In this paper we have shown that $\mathrm{Hg}$ adatom-modified $\mathrm{Au}$ surface could be easily prepared by simply dipping a Au surface into a $\mathrm{Hg}^{2+}$-containing solution and thus prepared surface exhibited four-electron reduction activity for molecular oxygen in strongly alkaline solutions. An $\mathrm{Al}-\mathrm{O}_{2}$ semi-fuel cell using this electrode as a cathode was constructed and its performance was tested.

\section{Experimental}

All the chemicals were of reagent grade otherwise stated. For voltammetric experiments, gold disk electrodes $\left(0.071 \mathrm{~cm}^{2}\right)$ were employed as a working electrode. They were sequentially polished with $1.0,0.3$, and $0.05 \mu \mathrm{m}$ alumina until mirror finish. After removing trace alumina from the surface by rinsing with deionized water and brief cleansing in an ultrasonic bath, they were immersed in a freshly prepared $10^{-2} \mathrm{M}$ mercury acetate solution for $2 \mathrm{~min}$. Thus prepared $\mathrm{Hg}$-adsorbed gold electrodes (denoted as $\mathrm{Au}-\mathrm{Hg}(\mathrm{dip})$ ) were again rinsed with deionized water. The same adsorption procedure was followed on $\mathrm{Au}$-sputtered PVC (Nuricell, Korea) for a fuel cell work. For comparison purpose, $\mathrm{Hg}$ adlayer was formed by underpotential deposition (UPD) ${ }^{16} \mathrm{Hg}$ UPD was done by dissolving $\mathrm{HgO}$ in $0.1 \mathrm{M} \mathrm{H}_{2} \mathrm{SO}_{4}$ to prepare $1 \mathrm{mM} \mathrm{Hg}^{2+}$ solution. After purging dissolved oxygen with $\mathrm{N}_{2}$, potential was scanned between 1.05 and $0.75 \mathrm{~V}$ at 10 $\mathrm{mV} \cdot \mathrm{s}^{-1}$. Thus prepared electrodes are denoted as $\mathrm{Au}-\mathrm{Hg}(\mathrm{upd})$.

The electrochemical set-up consisted of a classical three electrodes system (Autolab PGSTAT 30, Ecochemie, Nertherlans). The reference and counter electrodes were $\mathrm{Ag}|\mathrm{AgCl}| \mathrm{KCl}(3.5 \mathrm{M})$ and a platinum wire, respectively.

X-ray photoelectron spectra were collected by an XPS spectrometer (VG Microtech ESCA2000, England). Binding energy was calibrated with respect to carbon $1 \mathrm{~s}$ peak at $285 \mathrm{eV}$.

Acknowledgments. This work was supported by the National Research Foundation of Korea (NRF) grant funded by the Korea government (MEST) (No. 2010-0015726).

\section{References}

1. Kinoshita, K. Electrochemical Oxygen Technology; Wiley: New York, 1992.

2. Larminie, J.; Dicks, A. Fuel Cell Systems Explained; Wiley: New York, 2000.

3. Yeager, E. J. Electrochem. Soc. 1981, 128, 160C.

4. Ei-Deab, M. S.; Ohssaka, T. Electrochem. Commun. 2003, 5, 214.

5. Kao, W. H.; Kuwana, T. J. Am. Chem. Soc. 1984, 106, 473.

6. Su, Y. O.; Kuwana, T. J. Electroanal. Chem. 1990, 288, 177.

7. Strbac, S.; Anastasijevic, N. A.; Adzic, R. R. J. Electroanal. Chem. $1992,323,179$.

8. Adzic, R. R.; Markovic, N. M.; Vesovic, V. B. J. Electroanal. Chem. 1984, 165, 105.

9. Sarapuu, A.; Tammeveski, K.; Tenno, T. T.; Sammelselg, V.; Kontturi, K.; Schiffrin, D. J. Electrochem. Commun. 2001, 3, 446.

10. Hutton, H. D.; Pocard, N. L.; Alsmeyer, D. C.; Schueller, O. J. A.; Spontak, R. J.; Huston, M. E.; Huang, W.; McCreery, R. L.; Neenan, T. X.; Callstrom, M. R. Chem. Mater. 1993, 5, 1727.

11. Scherson, D. A.; Gupta, S.; Fierro, C.; Yeager, E.; Kordesch, M.; Eldridge, J.; Hoffman, R.; Blue, J. Electrochim. Acta 1983, 28, 1205.

12. Anson, F.; Shi, C.; Steiger, B. Acc. Chem. Res. 1997, 30, 437.

13. Katz, E.; Schmidt, H. L. J. Electroanal. Chem. 1994, 368, 87.

14. Barton, S. C.; Pickard, M.; Vazquez-Duhalt, R.; Heller, A. Biosens. Bioelectron. 2002, 17, 1071.

15. Collman, J. P.; Fu, L.; Herrmann, P. C.; Zhang, X. Science 1997, 275,949 . 
16. Matsumoto, F.; Uesugi, S.; Koura, N.; Okajima, T.; Ohsaka, T. J. Electroanal. Chem. 2001, 505, 150.

17. Matsumoto, F.; Uesugi, S.; Koura, N.; Ohsaka, T. J. Electroanal. Chem. 2003, 549, 71 .

18. Gileadi, E.; Kirowa-Eisner, E.; Penciner, J. Interfacial Electrochemistry; Addison-Wesley: London, 1975.

19. Carlson, T. A. Photoelectron and Auger Spectroscopy; Plenum Press: New York, USA, 1975.

20. Briggs, D.; Seah, M. P. Practical Surface Analysis; John Wiley \&
Sons, Inc.: New York, USA, 1996.

21. Hutson, N. D.; Attwood, B. C.; Scheckel, K. G. Environ. Sci. Technol. 2007, 41, 1747.

22. Shao, M. H.; Adzic, R. R. J. Phys. Chem. 2005, 109, 16563.

23. Schmidt, T. J.; Stamenkovic, V.; Arenz, M.; Markovic, N. M.; Ross, P. N. Electrochim. Acta 2002, 47, 3765.

24. Strbac, S.; Adzic, R. R. Electrochim. Acta 1996, 41, 2903.

25. Popovich, N.; Govind, R. J. Power Sources 2002, 112, 36.

26. Brodrecht, D. J.; Rusek, J. J. Appl. Energy 2003, 74, 113. 